(C) 2015

Панікар I. І., кандидат ветеринарних наук

Полтавська державна аграрна академія

\title{
МОРФОЛОГІЯ ЛІМФОЇДНИХ УТВОРЕНЬ, АСОЦІЙОВАНИХ ЗІ СЛИЗОВИМИ ОБОЛОНКАМИ ТРУБКОПОДІБНИХ ОРГАНІВ СВИНІ СВІЙСЬКОЇ НА РАННІХ ЕТАПАХ ПОСТНАТАЛЬНОГО ПЕРІОДУ ОНТОГЕНЕЗУ
}

\author{
Рецензент - доктор ветеринарних наук П. І. Локес
}

Визначено, щзо морфологічні особливості розвитку лімфоїдних утворень, асоиійованих зі слизовими оболонками трубкоподібних органів пов'язані з їх топографією $і є$ критерієм оцінки стану природної резистентності, неспецифічної та імунологічної реактивності організму поросят. Ïх цитоструктура представлена популяиією відповідних клітинних елементів. Динаміка відносної плоші лімфоїдних блямок змінюється нерівномірно: зростає у передній та середній частині порожньої кишки до 14-добового віку, у задній - до 7-добового, потім поступово зменшується до 29-добового віку.

Ключові слова: поросята, зовнішне середовище, травний тракт, лімфочити, лімфоїдні блямки, лімфоїдна тканина.

Постановка проблеми. Шлунково-кишковий тракт відноситься до відкритих систем організму, він є бар'єром для чужорідних білків, що проникають у канал органів травлення із зовнішнього середовища і утворений дифузною або вузликовою лімфоїдною тканиною, асоційованою зі слизовими оболонками $[5,10]$.

Аналіз основних досліджень і публікацій, у яких започатковано розв'язання проблеми. Імунокомпетенція слизової оболонки забезпечується великою кількістю різних компонентів вродженого імунітету та представниками нормальної мікрофлори [1]. Кишечник у значній мірі знаходиться під впливом екзогенних антигенів, водночас контакт із ними за тривалого проходження їжі через травний тракт $є$ дуже тісним. Тому не дивним $€$ той факт, що в ньому рясно представлена лімфоїдна тканина, якій належить важлива роль у периферійній імунній системі [3].

Слизова оболонка трубкоподібних органів травлення безпосередньо взаємодіє із зовнішнім середовищем. Тому вона невипадково містить лімфоїдні утворення, такі як кишкові бляшки, поодинокі та групові лімфоїдні вузлики $[4,7,8]$.

В імунній системі слизових оболонок можна умовно виділити дві ділянки: індуктивну (лімфоїдна тканина) та ефекторну (безпосередньо слизова оболонка). В першій відбуваються процеси імунологічного розпізнавання, презентації антигену, а також формується популяція антигенспецифічних лімфоїдних клітин. У ефекторній ділянці накопичуються Т-лімфоцити, що забезпечують клітинно-опосередковані форми захисту слизових оболонок $[6,9,11]$.

Метою роботи було визначення особливостей морфології лімфоїдних утворень слизової оболонки трубкоподібних органів поросят на ранніх етапах постнатального періоду онтогенезу.

Завдання: дослідити цитоструктуру, розміщення та ступінь розвитку лімфоїдної тканини лімфоїдних утворень в залежності від морфотопографії та віку тварин.

Матеріали і методи досліджень. Для гістологічного та морфометричного досліджень у клінічно здорових поросят відбирали частини 12-палої і порожньої кишок тонкого відділу кишечника.

Морфометричне дослідження проводили за допомогою аналізатора зображень, який складається 3 мікроскопа MikroMed 3 мікрофотонасадкою та 3 програмним забезпеченням Fly video серії EZ і персонального комп'ютера. Для вимірювання метричних характеристик використовували програмне забезпечення ImageJ for Windows ${ }^{\circledR}$ (version 2.00) в інтерактивному режимі з використанням об'єктива $\times 16$ і фотоокуляра $\times 10$. Для калібрування аналізатора зображень використовували проекцію поділок лінійки окулярмікрометра на лінійку об'єкт-мікрометра, що входять в комплект мікроскопа MikroMed [2].

Результати досліджень. Згідно 3 проведеними дослідженнями, лімфоїдний апарат 12-палої кишки поросят на ранніх етапах постнатального періоду онтогенезу сформований лімфоїдними клітинами епітеліального покрову, поодинокими лімфоїдними вузликам та лімфоїдними бляшками. Водночас лімфоїдні вузлики лімфоїдних бляшок розміщені дифузно. Їх цитоструктура представлена популяцією клітинних елементів: малими та середніми лімфоцитами, великими лімфоцитами та лімфобластами, ретикулярними клітинами та макрофагами, серед яких переважали малі та середні лімфоцити. 


\section{ВЕТЕРИНАРНА МЕДИЦИНА}

У порожній кишці містяться лімфоїдні поодинокі вузлики двох типів та лімфоїдні бляшки. В останніх до $65 \%$ і навіть більше лімфоїдної тканини було представлено куполоподібними лімфоїдними вузликами. Інша частина лімфоїдної тканини (до 35 \%) виявлялась у формі поверхнево розміщених вузликів. Між диференційованими та недостатньо диференційованими вузликами лімфоїдних бляшок знаходиться міжфолікулярна дифузна лімфоїдна тканина. Остання, у вигляді окремих скупчень лімфоїдних клітин, також виявляється між кишечними криптами та у підслизовій основі. Вторинні лімфоїдні вузлики займали усю підслизову основу, а їх купол випинається до епітеліального шару і знаходився між ворсинками слизової оболонки.
Клітинний склад лімфоїдного апарату тонкого відділу кишечника, що характеризує його потенційні властивості до захисту і формується під впливом різних імуногенних подразників представлений лімфоцитами (малими, середніми, великими), лімфобластами, ретикулярними клітинами та макрофагами.

3 віком поросят відбувається ріст і диференціація лімфоїдних бляшок, що призводить до зростання відносної площі їх лімфоїдної тканини, яка достовірно змінюється, залежно від відділу кишечника. Проте у 12-палій кишці та середній частині порожньої кишки щойно народжених та однодобових поросят лімфоїдні бляшки ще не сформовані, вони з'являються лише у поросят 7-добового віку.

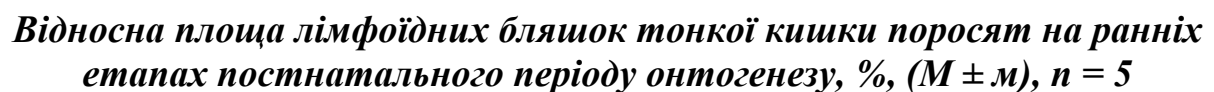

\begin{tabular}{|c|c|c|c|c|c|}
\hline \multirow{2}{*}{ Відділ кишечника } & \multicolumn{5}{|c|}{ Вік тварин } \\
\cline { 2 - 6 } & $\begin{array}{c}\text { 2 год. після } \\
\text { народження }\end{array}$ & 1 доба & 7 діб & 14 діб & 29 діб \\
\hline Дванадцятипала & - & - & $2,53 \pm$ & $3,48 \pm$ & $5,32 \pm$ \\
кишка & $1,84 \pm$ & $2,02 \pm$ & $1,42 \pm$ & $1,59 \pm$ & $1,4 \pm$ \\
\hline Передня частина & 0,123 & 0,118 & $0,084^{* * *}$ & 0,127 & 0,061 \\
порожньої кишки & - & - & $1,24 \pm$ & $1,69 \pm$ & $1,22 \pm$ \\
Середня частина & - & 0,054 & $0,094^{* * *}$ & $0,075^{* * *}$ \\
порожньої кишки & $0,98 \pm$ & $1,04 \pm$ & $2,06 \pm$ & $1,12 \pm$ & $1,47 \pm$ \\
Задня частина & 0,056 & 0,051 & $0,091^{* * *}$ & $0,092^{* * *}$ & $0,085^{* *}$ \\
\hline порожньої кишки &
\end{tabular}

Примітка: *- $<0,05, * *$ - $<0,01, * * *$ - $<<0,001$ (відповідно до попередньої групи)

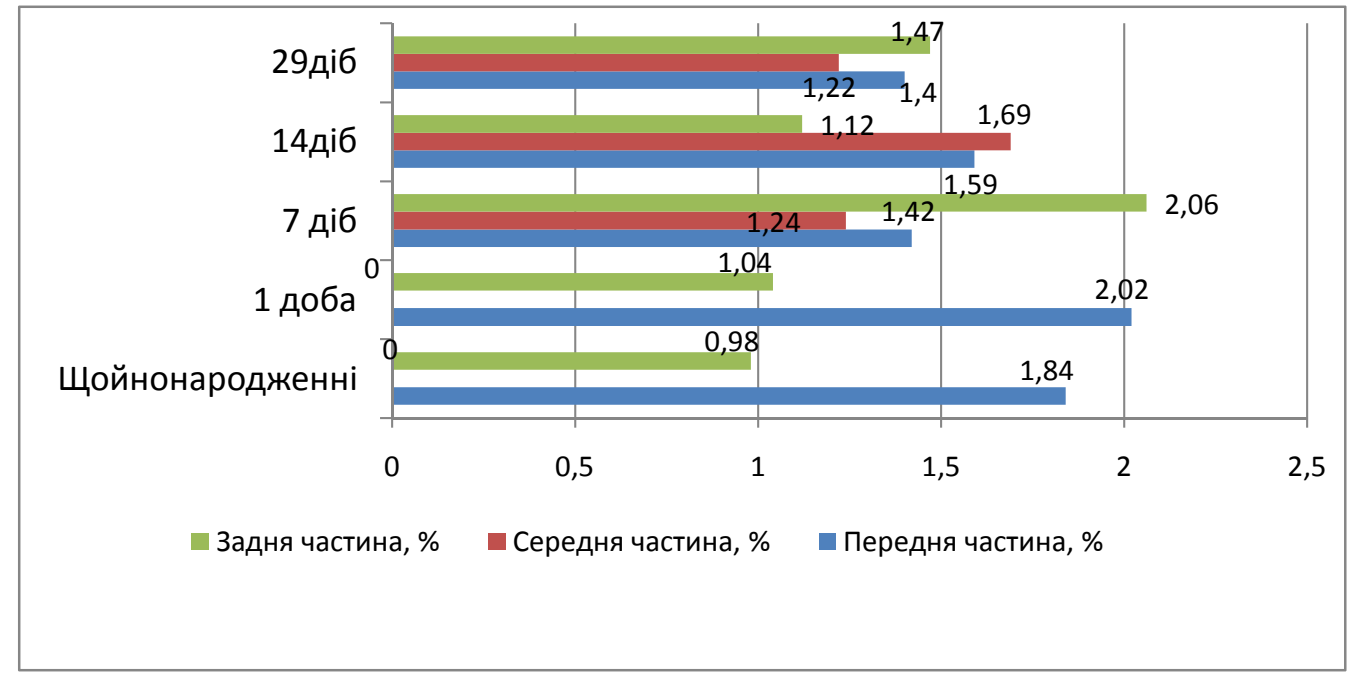

Рис. Динаміка відносної площі лімфоӥдних бляшок тонкої кишки поросят на ранніх етапах постнатального періоду онтогенезу 


\section{ВЕТЕРИНАРНА МЕДИЦИНА}

У середній частині порожньої кишки пік зростання спостерігається у віці 14 діб, у задній частині у 7 та 29 діб (див. табл., див. рис.).

Проведені морфометричні дослідження вказують, що відносна площа лімфоїдних бляшок 12-палої кишки з віком поросят послідовно зростає i у поросят у віці 29 діб дорівнює $5,32 \pm 0,211 \%$ (див. табл.). У передній частині порожньої кишки такі показники змінюються асинхронно, з піком їх зростання у поросят віку 1 та 14 діб.

Таким чином, ступінь розвитку лімфоїдної тканини лімфоїдних утворень, асоційованих зі слизовими оболонками трубкоподібних органів свині свійської на ранніх етапах постнатального періоду онтогенезу $є$ характерним для даного виду тварин і залежить від їх віку та морфотопо-

\section{БІБЛІОГРАФІЯ}

1. Андреева А. В., Муратова Е. Т. Иммунный статус, микробоценоз кишечника поросят при отъемном стрессе и их коррекция / А. В. Андреева, Е. Т. Муратова. - Уфа, 2010. - 166 с.

2. Горальський Л. П. Основи гістологічної техніки і морфофункціональні методи дослідження у нормі та при патології / Л. П. Горальський, В. Т. Хомич, О. І. Кононський // Житомир : вид-во Житомир ДАЕУ, 2005. - 284 с.

3. Кораблева Т. Р. Лимфоидные образования кишечника млекопитающих / Т. Р. Кораблева // Наукові праці ПФ НУБіП України «КАТУ» : cерія «Ветеринарні науки». - Сімферополь, 2011. Вип. 133. - С. 86-92.

4. Криштофорова Б. В. Морфофункціональний стан імунних утворів у новонароджених ссавців за дії ендо-екзогенних чинників / Б. В. Криштофорова // Вісн. держ. вищ. навч. закл. «Державний агроекологічний ун-т». - Житомир, 2008. №1 (21), T. 1. - C. 14-18.

5. Криштофорова Б. В. Імунокомпетентні структури шлунка як прояв природної резистентності організму в поросят / Б. В. Криштофорова, О. Прокушенкова // Ветеринарна медицина України, 2008. - №9. - С. 20-23.

6. Кухаркина О. В. Современные представления о строении, функции и иммунном ответе графії, і є критерієм оцінки морфофункціонального стану природної резистентності, неспецифічної та імунологічної реактивності організму тварин.

\section{Висновки:}

1. Формування та ступінь розвитку імунної системи проявляється структурно-функціональною перебудовою органо- і гістометричних показників лімфоїдних утворів слизових оболонок кишечника внаслідок адаптації новонародженого організму до умов існування.

2. Динаміка відносної площі лімфоїдних бляшок змінюється нерівномірно: зростає у передній та середній частині порожньої кишки до 14добового віку, у задній - до 7-добового, потім поступово зменшується до 29-добового віку.

слизистых оболочек / [О. В. Кухаркина, В. В. Дрыгин, О. А. Борисова и др.] // Ветеринарная патология. - 2007. - №4. - С. 24-28.

7. Овчаренко Л. С. Иммунная система слизистых оболочек и ассоциированная лимфоидная ткань: механизмы взаимодействия в норме и при патологии, пути их коррекции // Л. С. Овчаренко, А. А. Вертегел, Т. Г. Андриенко. - К. : ТОВ Видавничий дім «Здоров'я України», 2008. - №4. C. 25-30.

8. Пестова И. В. Морфогенез лимфоидной ткани ротоглотки, пищевода и желудка свиней : автореф. дис. на соиск. уч. степени к. б. н. : спец. 16.00 .02 «Патология, онкология и морфология животных» / И. В. Пестова. - Саранск, 2009. $18 \mathrm{c}$.

9. Blumberg $R$. Antigen presentation by intestinal epithelial cells / R. S. Blumberg, W. J. Lencer, Zhux // Immunol. Lett. - 1999. - V.68. - P. 7-12.

10. Gonzalez-Ariki $S$. The role of sympathetic innervation of the gut in regulating mucosal immune responses / S. Gonzalez-Ariki, A. J. Husband // Brain, Behavior and Immunity, 1998. - №12 (1). P. 53-56.

11. Mebius R. E. Organogenesis of lymphoid tissues / R. E. Mebius // Wature Rev. Immunology. 2003. - Yol. 3. - P. 292-303. 